Research articles

\title{
An ethnomethodological analysis of students' understanding of the concept of trigonometry in a high-stakes examination in South Africa
}

\author{
Marius Derick Simons. $^{1}$, Kadek Adi Wibawa ${ }^{2}$
}

\begin{abstract}
Abstrak Di Afrika Selatan, ujian matematika National Senior Certificate (NSC) adalah ujian tambahan yang diambil pada akhir dari dua belas tahun sekolah. Penelitian ini bertujuan untuk melakukan investigasi dan analisis tanggapan siswa peserta ujian matematika NSC terkait konsep trigonometri. Selain pendekatan etnometodologi yang secara umum dipakai dalam penelitian ini, pendekatan analitis dokumenter yang juga diadopsi terkait karakteristik ujian NSC, dalam hal inipeneliti hanya memiliki akses pada jawaban tertulis peserta ujian. Temuan utama penelitian adalah: (1) bahwa strategi dan taktik yang digunakan oleh peserta ujian sangat didorong oleh konteks ujian berisiko tinggi; (2) bahwa cara kerja peserta ujian menunjukkan struktur umum praktik yang biasa ditemukan dalam praktis diskursus matematika. Penelitian lebih lanjut diperlukan untuk memperdalam pemahaman tentang proses berpikir peserta ujian dengan melakukan wawancara kelompok terfokus, di mana peserta ujian diberikan kesempatan untuk menjelaskan cara kerja mereka dalam penilaian berbasis sekolah.
\end{abstract}

Kata kunci Tes berisiko tinggi, Trigonometri, Etnometodologi, Resisten, Akomodasi

\begin{abstract}
In South Africa, National Senior Certificate (NSC) mathematics examination is a capping external examination taken at the culmination of twelve years of schooling. The purpose of this study was to investigate and analyse the responses of examinees in the examinations in the concept of trigonometry. While the study mainly used an ethnomethodological approach, a documentary analytical approach was also adopted. Documentary analysis was necessitated by the private nature of the NSC examination, as we only had access to the written work of the examinees. The major findings were: (1) that the strategies and tactics used by examinees are highly driven by the context of the high-stakes examination; (2) that examinees' ways of working exhibit the general structure of the practice that is commonly found in mathematical discourse practices. Further studies are required to deepen the understanding of the thinking processes of examinees by conducting focus group interviews, where the examinees are afforded opportunities to explain their workings in school-based assessments.
\end{abstract}

Keywords High-stakes examination, Trigonometry, Ethnomethodological approach, Resistance, Accommodation

\section{Introduction}

Gained knowledge, whether useful or not, and retained over the years of schooling, and particularly when studying for an examination, becomes part of the items stored in memory. Examinees engaged in solution seeking actively attempt to retrieve the knowledge that is

\footnotetext{
${ }^{1}$ School of Science and Mathematics Education, University of the Western Cape, South Africa, mdsimons@uwc.ac.za

${ }^{2}$ Universitas Mahasaraswati Denpasar, Jl. Kamboja No. 11A, Denpasar, Indonesia
} 
specifically useful in the examination context from all other previously learned knowledge. However, in a high-stakes examination or any other school-based assessment, examinees are only allowed to respond to an examination question paper within a specified time, which means they are under pressure to access and retrieve the correct/context-appropriate knowledge. The realisation that knowledge is produced and accessed within specific situations - and in this case, time-sensitive and high-stakes examinations (Lave, 1988; Lerman, 2000; Wenger, 1998) thus requires us to move beyond an exploration of learning that relies solely on the psychology of the mind.

The above authors suggest that we also consider the context and setting of the learning situation. For instance, with regard to retrieving stored knowledge to respond to mathematics questions in a high-stakes examination, one must be mindful that the high-stakes examination room does not exist without a context. Whether knowledge is gained or retrieved, the situatedness remains important to the student. This study is an extension of chapter published in a book which reflect on Continuous Professional Development (CPD) of mathematics teacher (Julie, Smith, \& Holtman, 2019). The extension explored how the retrieval of knowledge in the NSC examination is visible in the written responses of examinees on the topic of trigonometry. In addition, the study analysed students' written works on the topic of trigonometry in the highstakes NSC examination as part of the Further Education and Training (FET) Phase in South Africa (Department of Basic Education (DBE), 2011).

\section{High-stakes examinations in the South Africa context}

The primary function of external examinations such as high-stakes NSC mathematics examinations, is, firstly, to sort and classify students according to their ability to do mathematics. More importantly, however, the results of these external examinations are used to make decisions that have serious consequences for schools, learners, and the education system. For example, the results are important for the learners because it determines whether they qualify for university, for schools because of prestige and allocation of future funding from government, and for the education system results have huge implications for curriculum reform. Therefore, the extent of the consequences attached to these examinations is what gives them their distinguishing features. Jacobs et al., (2014) point out that examinations serve a variety of purposes; for instance, the grades of these examinations can be used for placements in institutions of higher learning. In their classification of different examinations operating in the current South African schooling system, their study clearly shows that the NSC examination is heavily weighted in terms of external procedures and causal factors.

The NSC represents a high point in schooling for all Grade 12 learners in South Africa. As such, the final NSC examination may be regarded as the most important examination that South African learners write at the culmination of 12 to 13 years of schooling. It is a common practice that much of the teaching in the last three years of schooling is geared towards preparing learners to succeed in this examination. It is still by far the most popular determinant of access to higher tertiary education and, to a lesser extent, to the world of work; this makes it an unavoidable yet controversial form of assessment.

According to Brown, Lauder and Ashton (2008), the consequence of not obtaining an NSC certificate implies the exclusion of school-leavers (whether youth or adult learners) from the formal economy. Not achieving a good enough pass in the final NSC examination makes it much more difficult for learners to be accepted for further tertiary education. In the current education 
landscape, most of the focus when assessing subject performance has been on mathematics and science because the South African economy needs students in these fields particularly. Many researchers have examined the impact of high-stakes examinations on issues such as dropout rates and emotional impact on learners. For example, Griffin and Heidorn (1996) showed that high achievers experience a substantial drop in self-esteem, or they feel embarrassed in front of their peers for underperforming or failing. Their investigation infers that high-stakes examinations have a more pronounced effect on high achievers.

Madaus (1991) states that high-stakes examinations can be extremely stressful, and that they can have a negative effect on a student's personality, which ultimately influences their selfconcept and self-esteem. Schmidt, Lerew and Jackson (1999) studied the impact of stress on students who repeatedly failed standardised tests, specifically on those students who were not expected to fail. According to their interview data, failing such important tests damages students' self-belief, has a negative impact on their relationship with their parents, and alters their future educational and career plans. Literature surveys in educational research (Harlen \& Deakin Crick, 2002; Kluger \& DeNisi, 1996) show that the effect of learning through memorisation reduces creativity and innovation. A study done by Barksdale-Ladd and Thomas (2000) confirmed the view that high-stakes testing may in fact harm learners' health by causing excessive anxiety and stress. Wheelock, Bebell and Haney (2000) found evidence of this, such as anxiety, anger, and pessimism, particularly among older students.

The above research gives an idea of the contextual features and the psychological impact of the NSC examination on the examinees. This study is concerned with such examinees' ways of working, specifically with reference to seeking solutions to trigonometry problems in the highstakes NSC mathematics examination.

\section{Trigonometry as mathematics topic}

Trigonometry requires learners to have knowledge of several sophisticated mathematical concepts, such as "the association of numbers with the sides of a triangle representing length, measure of angles, ideas of ... and symbolic notation" (Raj \& Nega, 2011, p. 236). For learners to pursue engineering, physics, construction, and design, they must develop a basis of trigonometric knowledge in school. Hence, trigonometry has an important place in the mathematics curriculum in many countries, even though its curriculum may vary from country to country at secondary school level (Delice \& Roper, 2006). Trigonometry is a compulsory topic for all Grade 10 to 12 learners who do mathematics in South Africa. Orhun (2004) studied the difficulties that learners encountered when using trigonometry to solve problems; he/she found that learners did not fully understand or develop the concepts of trigonometry and thus made some errors (Chinnappan, Nason \& Lawson, 1996). This is not only the case in South Africa. According to Thompson (2008), middle school and secondary school learners in the United States of America (USA) also find trigonometry especially difficult. He claims that the difficulty of trigonometry lies in an incoherence of foundational meanings developed in the lower grades - similar findings emerged from other studies (Gür, 2009; Sofiyah, 2018; Walsh, Fitzmaurice, \& O’Donoghue, 2017). Weber (2005) also states that students find it difficult to learn trigonometric ideas and concepts, and that the causes of these difficulties seem to be multifaceted and interrelated - a view shared by Sofiyah (2018) and Orhun (2004). The challenges and pressures related to high-stakes examinations as well as the difficulties experienced by examinees when engaging with trigonometry problems is what this paper aims 
to expose by using Garfinkel's (1967) concept of ethnomethodology and the notion of agency put forward by Pickering (1995) with reference to resistance and accommodation. These concepts will be discussed below.

\section{Theoretical Framework}

\section{Ethnomethodology}

The theoretical framework for this paper draws on the concept of ethnomethodology (Garfinkel, 1967), which looks at how ordinary people use commonsense knowledge, procedures and considerations to gain an understanding of everyday situations. Ethnomethodology is the study of practical action and practical reasoning (Garfinkel, 1991), in order to clarify a theoretical conception of social phenomena, such as social order, social facts, social structures, reflexivity, accountability and ethnomethodological indifference. This paper thus uses ethnomethodology to explore the constitutive, situated nature of mathematical work. The objective of ethnomethodology is to extract the social facts from the practical social actions (Simons, 2016). The process of doing so is clarified in Durkheim's (1950) description of sociological studies, in which he established the objective reality of social facts as a fundamental principle of sociology. From an ethnomethodological perspective, examinees as actors in the examination room themselves produce social facts, or conduct themselves in such a way that produces and makes visible the social facts. In turn, the social conditions (of high-stakes examinations, in this case) determine what actors (examinees) do. All the properties of the social order are thus made visible locally (in situ) with the result that social scientists and ethnomethodologists can see what participants are doing. Liberman (2012) agrees that the organisation of social order occurs naturally in its setting.

The concepts of social order and social action cannot be approached independently, as they occur in a cyclical process (Coulon, 1995), which makes the constitutive characteristics of social facts and social action an unavoidable part of the mathematical production and makes the detail of mathematical production important. Dourish and Button (1998) emphasise the fact that practical social action attracts attention to how participants do it, and how the production and understanding of the social actions are formed "for practical purposes". The practical social action exists in all thinking processes, and in the choice of mathematical skills selected to accomplish what was set out for the examinee to achieve. Examinees' solutions to mathematical problems are only part of the account of their understanding of mathematics, in terms of the totality of the natural occurrence in situ. The interaction of examinees and all relevant role players in the examination room is part of the distinctive, stable arrangement of the institution of the high-stakes NSC examination. In its exploration of examinees' ways of working, this study analysed the dialectic production of mathematics within a social order, and is concerned with responses that indicate how examinees go about doing the work and interpreting the examination questions in situ.

\section{Pickering's notions of resistance and accommodation}

Pickering defines the "occurrence of a block on the path to some goal" as a form of resistance (Pickering, 1995, p.569). This resistance is accommodated by different interactions. Pickering (1995) thus sees accommodation as a tentative human approach that circumvents obstacles. A reversal is an example of such a way of working: when a learner arrives at a point 
of resistance in his/her calculations, the learner removes the produced work in the process of accommodating for that particular resistance (Julie, 2003), and starts over with the same solution-seeking approach but along a new path, with a different strategy, until a result is reached. Another way of working uses the notion of a 'convenience', where the examinee creates a problematic situation by using a faulty method to simplify a mathematical problem to arrive at a suitable objective (Julie, 2003). This way of working shows the abandonment of a completed solution-seeking pursuit and the examinee's recommencement with minor adjustments to their first attempt to reach the objective given in the problem text.

\section{Research Questions}

This study therefore sought to answer the following research questions on the topic of trigonometry based on the written responses from the high-stakes NSC examinations:

1. What are the characteristics of the dialectic resistance and accommodation of 'reversal', which were observed in the students' solutions on the topic of trigonometry?

2. What are the characteristics of the dialectic resistance and accommodation of 'convenience', which were observed in the students' written work on the topic of trigonometry?

\section{Methods}

A qualitative research design was followed in this study; this meant that examinees' ways of working in producing their responses to questions in a high-stakes examination were used to describe the phenomena under investigation. According to Jacob (1987), a qualitative research methodology attempts to present the data from the perspective of the learners, in this case. Denzin and Lincoln (2011) describe qualitative research as a set of interpretive, material practices that make the world visible.

The research for this study was done within the framework of ethnomethodology. The analysis was thus guided by ethnomethodological principles, such as reflexivity with the notion of building up accounts to make sense of the problem text, indexicality and an overall approach of being non-judgmental thus the idea of ethnomethodological indifference. Coupled with these principles is the dialectic of resistance and accommodation that unobtrusively influenced the underlying techniques. Data was gathered from the high-stakes NSC examination that had been written in 2012. The data were organised by means of a convenience sampling strategy. This sampling strategy fits into the already selected sample called Local Evidence-Driven Improvement of Mathematics Teaching and Learning Initiative (LEDIMTALI). It is a project where educators, mathematics educators, mathematicians, and curriculum advisors collectively and collaboratively work to ultimately induce the learners' achievement at their highest potential in mathematics (Julie, 2011). The sample of schools in the LEDIMTALI was chosen according to the inputs agreed upon by all relevant role-players: ten schools were part of the initiative, schools were all functional, schools were from the same district, and the school had at least one class for mathematics at Grade 12 level.

From above selection criteria 10 schools were selected all based in the Western Cape Province in South Africa. The total number of mathematics question papers (Paper 2) of all ten schools amounted to 380. Furthermore, only questions on trigonometry were selected for analysis. Therefore, as noted earlier, only the questions pertaining trigonometry in Paper 2 (Questions 8.9.10.11, and 13) were selected for analysis. All these questions were scrutinized and questions which showed visible textures in the ways of working were selected. 94 scripts 
were found to have some form of texture. Here the textures are a product of the ways of working of examinees. In other words, the textures represent some type of abandonment of a pursuit in a solution-seeking path. The ways of working as put earlier are responses to the problem text in pursuit of a suitable solution.

\section{Findings}

Through the dialectic of resistance and accommodation and the ethnomethodological constructs, the textures of the examinees' ways of working in their pursuit of an objective or a solution became noticeable. The dialectic of resistance and accommodation, as explained by Pickering (1995), where resistance denotes the failure to achieve an intended outcome, is captured by the agency in practice. Accommodation is an active human strategy of responding to a resistance, which can include concepts like adaptations, inclusions and exclusions, among others. This happens when there is a 'looking back' or a revision of goals and intentions. When the resistance goes unnoticed, it is a case of non-firing of resistance. In the following section, an analysis of students' dialectic resistance and accommodation of 'reversal' and 'convenience' is presented, based on the students' written work on the topic of trigonometry from the 2012 highstakes examination.

\section{Reversal}

Julie (2003, p.121) posits that "reversal is where a calculated resistance was created and the learner removes the produced work by drawing a line through it and starts over immediately from a certain point". The re-start is on the same solution-seeking path, albeit with a different strategy, until a result is reached. Figure 1 is a learner's response to Question 9.2 from Paper 2 of the 2012 high-stakes NSC mathematics examination.

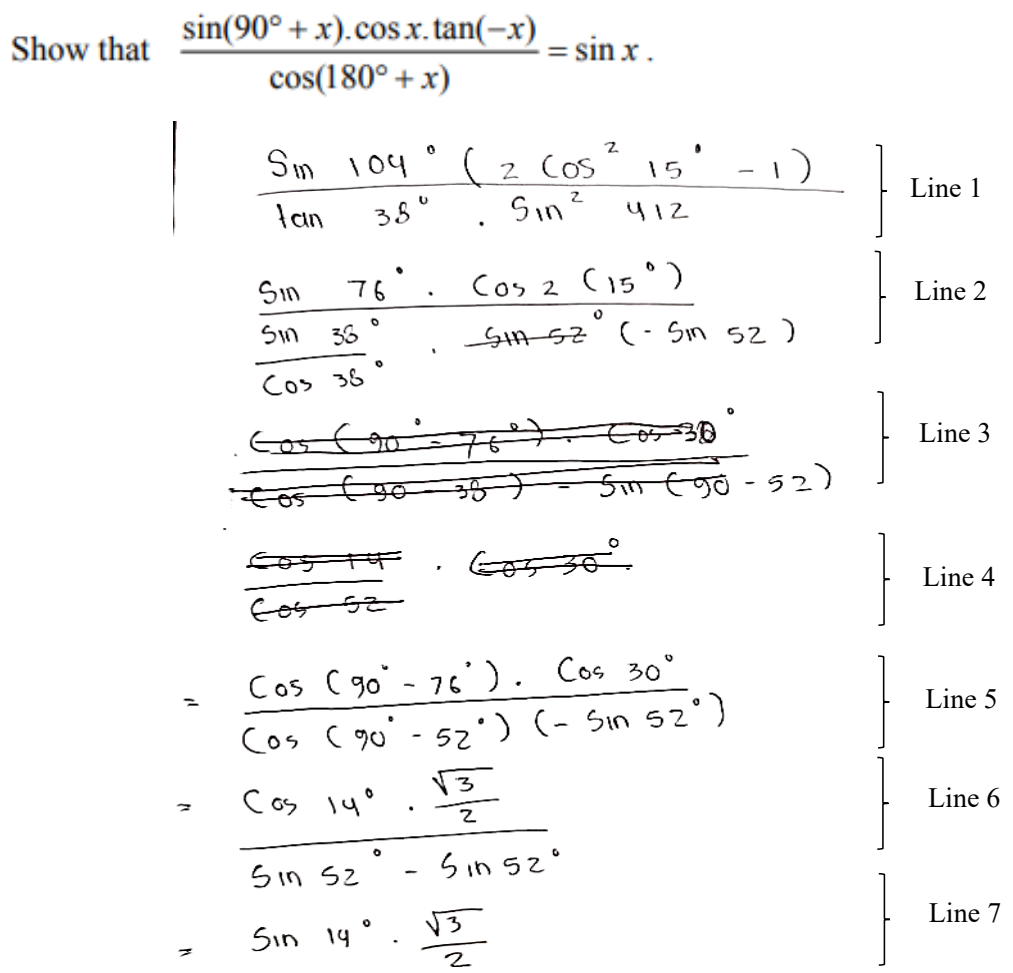

Figure 1. Reversal - an example of a student's work 
As with the solution-seeking paths illustrated in Figure 1, the learner starts by writing down the symbolic objective in line 1, which is part of the question. Line 2 of Figure 1 shows the examinee replacing $\sin 104^{\circ}$ by the acute angle for the relationship $\sin \left(180^{\circ}-104^{\circ}\right)$ to $\sin 76^{\circ}$. The examinee then uses the trigonometric relationship of double angles to transform $\left(2 \cos ^{2} 15^{\circ}-1\right)$ to $\cos 2\left(15^{\circ}\right)$. The next steps show the examinee using the identity relationship to substitute $\tan 38$ with $\frac{\sin 38^{\circ}}{\cos 38^{\circ}}$ in line 2 of Figure 1. The reduction formula of $\sin \left(360^{\circ}+52^{\circ}\right)=\sin 52^{\circ}$ is also used to express $\sin ^{2} 412^{\circ}$ as $\left(-\sin 52^{\circ}\right) .\left(-\sin 52^{\circ}\right)$. The following steps show the produced work in lines 3 and 4 abandoned and scratched out, upon obtaining $\cos 14^{\circ}$ and $\cos 52^{\circ}$ in line 4 . The re-starting point, or 'reversal', is where the examinee copies the abandoned work $\cos \left(90^{\circ}-76^{\circ}\right)$ and $\cos 30^{\circ}$ in the exact form - the numerator in line 3 to the numerator in line 5 - of Figure 1. The examinee has thus moved back and now follows a different strategy to fit the mathematical context. In the same instance, the examinee adapts $\cos (90-38)$ to $\cos (90-52)$ and then evaluates it as $-\sin 52$. Line 5 of Figure 1 shows that the examinee replaces $\cos 14^{\circ}$ with $\sin 14^{\circ}$ and $\cos 52^{\circ}$ with $\sin 52^{\circ}$. The approach proceeds in line 6 of Figure 1, showing the simplification of the work in line 5 of Figure 1 and giving the expression $\frac{\sin 14 \cdot \frac{\sqrt{3}}{2}}{\sin 52^{\circ}-\sin 52^{\circ}}$. The last part of the answer sees the examinee simplifying $\cos 30^{\circ}$ with its angle-side ratio of $\frac{\sqrt{3}}{2}$, and cancelling $\sin 52^{\circ}-\sin 52^{\circ}$ to obtain $\sin 14^{\circ} \cdot \frac{\sqrt{3}}{2}$ as a final result.

\section{Convenience}

Julie (2003, p.121) states that "convenience is where the examinee creates a situation using a faulty method to simplify a mathematical problem to get to a suitable objective". This way of working shows the abandonment of a completed pursuit and the examinee's recommencement with minor adjustments to their first attempt to reach the objective given in the problem text. Figure 3 shows a response to Question 11.1 of Paper 2 in the 2012 NSC mathematics examination.

\section{QUESTION 11}

$\mathrm{ABCD}$ is a parallelogram with $\mathrm{AB}=3$ units, $\mathrm{BC}=2$ units and $\mathrm{ABC}=\theta$ for $0^{\circ}<\theta \leq 90^{\circ}$.

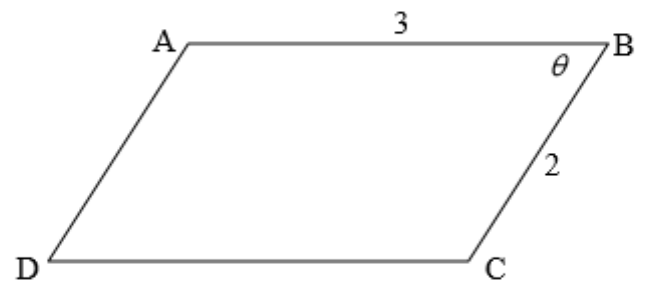

11.1 Prove that the area of parallelogram $\mathrm{ABCD}$ is $6 \sin \theta$

11.2 Calculate the value of $\theta$ for which the area of the parallelogram is $3 \sqrt{3}$ square units.

Figure 2. November 2012 NSC Mathematics Paper 2, Question 11 


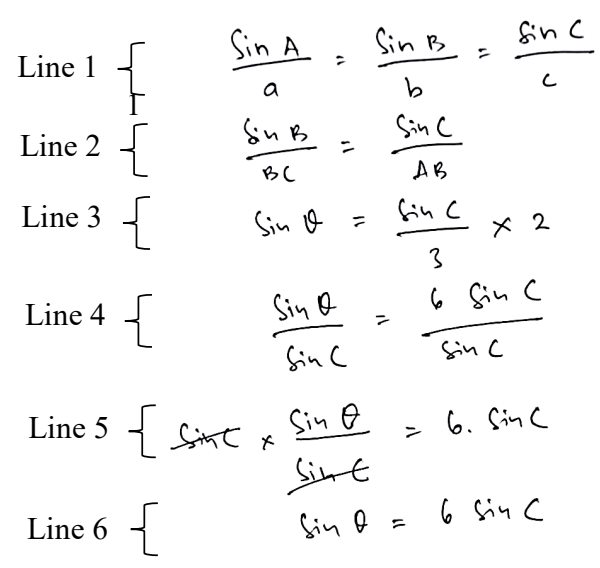

Figure 3. Convenience: Abandonment labeled as rough work - an example of a student's work

In line 1 of Figure 3, the examinee copies the formula in the inverse form as $\frac{\sin A}{a}=\frac{\sin B}{b}=$ $\frac{\sin C}{c}$ from the information sheet. Line 2 of Figure 3 shows the values of $a$ replaced by $B C, b$ replaced by $A B$ and $c$ unchanged. In line 3 of Figure 3, $B C$ is substituted by 2 and $A B$ by 3 . In line 4 of Figure 3, the examinee produces $6 \sin C$ as a solution for $\frac{\sin C}{3} \times \frac{2}{1}$. Both sides of the equation in line 4 are then divided by $\sin C$, which renders $\frac{\sin \theta}{\sin C}=6 \sin c$. Further work in line 5 of Figure 3 shows the examinee multiplying both sides of the equation with $\frac{\sin c}{1}$ to obtain a solution of $\sin \theta=6 \sin C$ in line 6 . This way of working leads to the complete abandonment of the response and is labelled as rough work:

$$
\begin{aligned}
& \frac{\sin A}{a}=\frac{\sin B}{b} \quad \text {. Line } 1 \\
& \frac{\sin B}{b}=\frac{\sin A}{a} \quad \text {. Line } 2 \\
& \text { b. } \left.\frac{\sin \theta}{b}=\frac{\sin A}{a} \cdot b\right] \text { Line } 3 \\
& \left.\sin \theta=\frac{\sin A}{2} \cdot 3\right] \text { Line } 4 \\
& \begin{array}{l}
A B \times B C=\sin \theta \\
3.2=\sin \theta
\end{array} \quad \text { Line } 5 \\
& 6=\sin \theta \quad \text { Line } 6
\end{aligned}
$$

Figure 4. Convenience: New pursuit with minor adjustments - an example of student's work

The new pursuit sees the examinee persisting with the same formula. Line 1 of Figure 4 shows the examinee copying $\frac{\sin A}{a}=\frac{\sin B}{b}$ from line 2 of the previous response with an adjustment to the formula by excluding $\frac{\sin C}{c}$. In line 3 of Figure 4, the examinee continues to multiply both 
sides of the equation with ' $b$ '. Further work in line 4 of Figure 4 sees the examinee substitute 2 in the place of ' $a$ ' and 3 in place of ' $b$ '. Line 5 of Figure 4 shows $\frac{\sin B}{b}$ replaced by $\sin \theta$. The examinee leaves $6=\sin \theta$ as the result.

\section{Discussions}

\section{Reversal}

After writing down the symbolic objective in line 1 of Figure 1, the examinee continued seeking a solution. After making use of various trigonometric relationships, such as side angle relationships of right-angled triangles, acute angle relationships and double angles, the examinee's pursuit rendered $\left(-\sin 52^{\circ}\right) \cdot\left(-\sin 52^{\circ}\right)$ in line 2 of Figure 1 . However, the expression $\left(-\sin 52^{\circ}\right) \cdot\left(-\sin 52^{\circ}\right)$ upon rendering the negative," $-"$ ", signs of the expression in the brackets. The exertion of agency occurred when the examinee 'saw' $\sin$ as negative in the fourth quadrant. The $360^{\circ}$ obtained in the evaluation process contributed to this deduction, because the normal course of teaching a relationship with $360^{\circ}$ is associated with the fourth quadrant. In line 2 of Figure $1, \cos 38^{\circ}$ and $\left(-\sin 52^{\circ}\right)$ were both cancelled, as indicated by the arrows pointing to cancelled parts of the fraction in line 2 . It was clear from the deleted part ( $\cos 38)$, which appeared in the numerator of the expression $\frac{\sin 38}{\cos 38}$ and $\left(-\sin 52^{\circ}\right)$, that the objective was to obtain the same ratio in terms of $\cos$. This way of working illustrates a case of reflexivity, where things done before were referred to, whilst changing direction.

In line 4 of Figure 1 , the method rendered $\cos 14^{\circ}$ and $\cos 52^{\circ}$. Although $\cos 14^{\circ}$ and $\cos 52^{\circ}$ flow from the previously produced proceeding step, it did not comply with the chosen mathematical context to achieve an objective "without the calculator" as per examination requirement, and thus this abandonment indicated the calculated resistance caused by the mathematical context in terms of the direction taken in the solution-seeking pursuit. Further work after the abandonment showed that the examinee copied $\cos \left(90^{\circ}-76^{\circ}\right)$ and $\cos 30^{\circ}$ in the exact form from the numerator in line 3 to the numerator in line 5 of Figure 1. The examinee thereafter moved back and followed a different strategy to fit the mathematical context. In the same instance, the examinee adapted $\cos (90-38)$ to $\cos (90-52)$ and then evaluated it as $-\sin 52$. This could be observed in line 5 of Figure 1, where it showed the examinee replacing $\cos 14^{\circ}$ with $\sin 14^{\circ}$ and $\cos 52^{\circ}$ with $\sin 52^{\circ}$.

The pursuance of solution seeking shows the rationality of work from the abandoned pursuit that might still be appropriate in its exact form, or that might need some reworking but could still lead to a desired result "without the calculator". The ways of working up to this point show the continued non-firing of resistance in terms of the retention of $\cos (90-76)$ by rendering it as $\sin 14^{\circ}$. The evaluation of $\cos (90-76)$ in terms of the acute angle relation would have taken the pursuit back to line 2 , thus ending up with $\sin 76$. Although $\sin 14^{\circ}$ exerted agency in terms of the use of the co-function, and the examinee persisted with it up to the final result.

\section{Convenience}

The texture of ways of working emanating from the analysis started with the examinee writing down the formula to prove the area of the parallelogram equal to $6 \sin \theta$. The examinee's interpretation of the area of the parallelogram was triggered by the formula given in the formula sheet, which showed $\triangle A B C: \frac{a}{\sin A}=\frac{b}{\sin B}=\frac{c}{\sin C}$. The selection of this formula exerted agency 
in the form of a 'convenience', which indicated the use of a faulty method in pursuance of a suitable solution, in order to prove the objective given in the problem text. The examinee 'saw' the diagram in Figure 2, which represented parallelogram ABCD, consisting of two triangles, which allowed the mathematical argument to prove its area, $\mathrm{ABCD}=6 \sin \theta$. The concept of congruent and similar triangles made up the mathematical argument in relation to the information given in the text and the diagram in Figure 2, as well as the formulae provided in the information sheet.

The work in line 2 of Figure 3 showed the examinee had cross-multiplied $B C$ with $\frac{\sin B}{b}$ and $\frac{\sin C}{c}\left[\frac{B C}{1} \times \frac{\sin A}{a}=\frac{\sin B}{b} \times \frac{B C}{1}\right]$ and omitted $\frac{\sin A}{a}$, probably because there are only two values given in the diagram ABCD in Figure 3. The examinee's way of working was towards a formulation where given values could be used. The examinee thus replaced $\sin B$ with $\sin \theta$ on the right side of the equation in line 3 of Figure 3. This is probably due to the position of $\theta$ in parallelogram $A B C D$ in Figure 2. The diagram in Figure 2 shows $\theta$ as angle $B$, which is noticeable in the given problem text, " $A \widehat{B} C=\theta$ ". The work produced up to the final answer was abandoned and a new pursuit was started. The rough work shown in Figure 3 was a completed solution. This was not in the form of helpful notes, scribblings or short reminders of what were important planned calculations. It was not of a kind common in the way of working in mathematics when learners do rough work in the margin of the page or in a space away from the original pursuit. In this instance, contributing to this form of labelling was the instruction given to examinees in the NSC examination, to do all rough work on the examination script.

Plausibly the examinee checked the result in line 6 of Figure $4, \sin \theta=6 \sin c$ against the problem text to "prove the area of parallelogram $\mathrm{ABCD}=6 \sin \theta$ ". The examinee found that the result was not suitable in terms of the objective given in the problem text. Such checking is part of the examinee's historicised mathematical knowledge. A common instruction given by teachers to learners and by invigilators to examinees is to "make sure of your answer". It was this type of checking that triggered the resistance and that caused the examinee to label the work as rough work and draw lines through it.

In the new pursuit, the work showed some adjustments; however, the examinee still used a method that did not serve the purpose of obtaining a suitable solution. The continuation of this way of working showed the non-firing of in terms of 'convenience'. This might be due to the representation of $\sin$ in the sine rule formula as shown in the information sheet and the $\sin$ in $6 \sin \theta$ given in the problem text. The exclusion of $\frac{\sin C}{c}$ was to accommodate for the result in line 6 of Figure 3 in the abandoned pursuit. The adjustment of the formula probably led to the expectation that the pursuit would render something closer to the objective. The examinee's way of working - of replicating and adjusting work (see from Figure 2, as used in Figure 4) - shows reflexivity. Although the work in Figure 3 was labelled as rough work, the examinee saw this work as part of the evidence of a solution-seeking pursuit to solve a mathematical problem. However, it also indicates that the examinee saw this work as useful and as a relevant attempt to do the actual work that would produce a suitable solution.

The examinee's ways of working in line 6 of Figure 4 start out with " $\therefore$ ", which means "therefore", thus showing that what follows is derived from the previous work. This notion of making " $\therefore$ " is a pursuance that shows procedural fluency, giving reason and meaning to the path that had been travelled so far. However, the pursuit re-routed to a totally different path by taking the given information and constructing a final answer. The re-routed path shows the 
examinee writing $A B \times B C=\sin \theta$ and substituting $A B \times B C$ with 3 and 2 respectively. The examinee then multiplies " $3 \times 2$ " and leaves the outcome as $6=\sin \theta$ in line 7 of Figure 4 . In this instance, the problem text probably exerted agency, which brought the examinee's work closer to the given objective stated in the problem text. The pattern of work that emerged from this analysis is of a kind in which agency is exerted upon the examinee's path of pursuing a solution to a mathematical problem. The foregoing discussion indicates that the ways of working and the exertions of agency led to a resistance in the solution-seeking path was then accommodated for. In some cases, agency was exerted, and the non-firing of resistance occurred.

\section{Conclusion, Implication and Further Research}

This study has contributed towards exposing the practices that learners engage in when solving mathematical problems in high-stakes examinations. It has shown how examinees engaged the problem text, resulting in various ways of working along solution-seeking paths. In addition, the study adds value to the type of feedback generated within high-stakes NSC mathematics examination. It illustrates an alternative type of feedback, which can be extracted from the learners' ways of working with trigonometry. Furthermore, this study has contributed to the drive of the South African Department of Basic Education (DBE) to improve mathematics results in our schools.

According to the findings of this study, the method of doing mathematics in a high-stakes examination resembles a mathematician-like way of working. As suggested by Schoenfeld (1987), it should therefore be the aim of mathematics educators to introduce learners to such mathematics practices. Julie (1992) goes further, asserting that learners should be given the opportunity to practise this mathematician-like way of doing mathematics at their own level.

Furthermore, teachers need to see examples, such as the abandoned work presented in the analysis, as a useful object of teaching and learning. When teachers allow learners to make sense of this solution-seeking process, it will foster a greater understanding of their own ways of ways of working in a time-restricted examination. According to Lampert (1990), the content of mathematical lessons should show mathematical contexts that expose learners to strategies that support or reject solutions instead of simply searching for the answer. This way of doing mathematics should furthermore encourage interaction between learners to discuss their solution-seeking strategies. The resulting meaning-making will give learners a greater understanding of their own ways of working. This process of getting learners to analyse, explain, and interpret when they abandon an approach will also provide learners with more direct feedback, which will in turn improve their understanding of their own work in a specific mathematical context.

Watson and Mason (2006) argue that the use of such mathematical objects even in highly organised situations in which learners reach for the same answers or practical accomplishments using the exact same data, may offer learners experiences. It would allow teachers to plan their teaching from the learners' perspectives.

Future research may involve the practice of encouraging collaborative group work among learners to ascertain the strategies learners employ when analysing and interpreting responses taken from school-based assessments, such as class tests and examinations as well responses from high-stakes examinations. In addition, further studies are required to deepen the understanding of the thinking processes of examinees by, for instance, conducting focus group 
interviews where examinees are afforded opportunities to explain their workings in a schoolbased assessment.

\section{References}

Barksdale-Ladd, M. A., \& Thomas, K. F. (2000). What's at stake in high-stakes testing? Teachers and parents speak out. Journal of Teacher Education, 51(5), 384-397.

Brown, P., Lauder, H., \& Ashton, D. (2008). Education, globalisation and the future of the knowledge economy. European Educational Research Journal, 7(2), 131-156. Doi: 10.2304/eerj.2008.7.2.131

Chinnappan, M., Nason, R., \& Lawson, M. (1996). Pre-service teachers' pedagogical and content knowledge about trigonometry and geometry: An initial investigation. In P. C. Clarkson (Ed.), Proceedings of the 19th Annual Conference of the Mathematics Education Research Group of Australasia. Melbourne: MERGA.

Coulon, A. (1995). Ethnomethodology. Thousand Oaks, California: Sage Publications.

Delice, A., \& Roper, T. (2006). Implications of a comparative study for mathematics education in the English education system. Teaching Mathematics and its Applications: An International Journal of the IMA, 25(2), 64-72. Doi: 10.1093/teamat/hri007

Denzin, N. K., \& Lincoln, Y. S. (2011). The SAGE handbook of qualitative research. Sage.

Department of Basic Education (DBE). (2011). Curriculum and assessment policy statement: Grades 10 12. Pretoria: Mathematics.

Dourish, P., \& Button, G. (1998). On "technomethodology": Foundational relationships between ethnomethodology and system design. Human-computer Interaction, 13(4), 395-432. Doi: $10.1207 / \mathrm{s} 15327051 \mathrm{hci} 13042$

Durkheim, E. (1950). The rules of sociological method. (8th ed. / translated by Sarah A. Solovay and John H. Mueller, and edit ed by George E.G. Catlin). Glencoe, Illinois: Free Press.

Garfinkel, H. (1967). Studies in ethnomethodology. Englewood Cliffs, N.J: Prentice-Hall.

Garfinkel, H. (1991). Respecification: Evidence for locally produced, naturally accountable phenomena of order, logic, meaning, method, etc. in and as of the essential haecceity of immortal ordinary society I-an announcement of studies. In G. Button. (Ed.), Ethnomethodology and the human sciences (pp. 10-19). New York, NY: Cambridge University Press.

Griffin, B. W., \& Heidorn, M. H. (1996). An examination of the relationship between minimum competency test performance and dropping out of high school. Educational Evaluation and Policy Analysis, 18(3), 243-252.

Gür, H. (2009). Trigonometry learning. New Horizons in Education, 57(1), 67-80.

Harlen, W. \& Deakin, C. R. (2002). A systematic review of the impact of summative assessment and tests on students' motivation for learning (EPPI-Centre Review, version 1.1). In Research Evidence in Education Library. London: EPPI-Centre, Social Science Research Unit, Institute of Education, University of London. Retrieved from https://eppi.ioe.ac.uk/cms/Default.aspx?tabid=108

Jacob, E. (1987). Qualitative research traditions: A review. Review of Educational Research, 57(1), 150. Doi: $10.3102 / 00346543057001001$

Jacobs, M., Mhakure D., Fray, R.L., Holtman, L., \& Julie, C. (2014). Item difficulty analysis of a highstakes mathematics examination using Rasch analysis. Pythagoras, 35(1), 1-7. Doi: 10.4102/pythagoras.v35i1.220

Julie, C. (1992). Doing Mathematics - What does it mean? Unpublished keynote address presented at The Second Annual Convention of the Mathematics Association of Transkei. Transkei Inservice College: Mthatha.

Julie, C. (2003). Work moments in mathematical modelling by practising mathematics teachers with no prior experience of mathematical modelling and applications. New Zealand Journal of Mathematics, 32 (Supplementary Issue), 117-124.

Julie, C. (2011). LEDIMTALI brochure. Bellville: University of the Western Cape. 
Julie, C., Smith, C. R. \& Holtman, L. (Eds.) (2019). Caught in the Act-Reflections on continuing professional development of mathematics teachers in a collaborative partnership. Stellenbosch: African Sun Media.

Kluger, A. N., \& DeNisi, A. (1996). The effects of feedback interventions on performance: A historical review, a meta-analysis, and a preliminary feedback intervention theory. Psychological Bulletin, 119(2), 254-284. Doi: 10.1037/0033-2909.119.2.254

Lampert, M. (1990). When the problem is not the question and the solution is not the answer: Mathematical knowing and teaching. American Educational Research Journal, 27(1), 29 - 63. Doi: $10.3102 / 00028312027001029$

Lave, J. (1988). Cognition in practice: Mind, mathematics and culture in everyday life. Cambridge University Press. Doi: 10.1017/CBO9780511609268

Lerman, S. (2000). The social turn in mathematics education research. In J. Boaler (Ed.), Multiple Perspectives on Mathematics Teaching and Learning (pp. 19-44). Westport, CT: Ablex.

Liberman, K. (2012). Semantic drift in conversations. Human Studies, 35(2), 263-277. Doi: $10.1007 / \mathrm{s} 10746-012-9225-1$

Madaus, G. F. (1991). The effects of important tests on students: Implications for a national examination system. The Phi Delta Kappan, 73(3), 226-231.

Orhun, N. (2004). Students' mistakes and misconceptions on teaching of trigonometry. Journal of Curriculum Studies, 32(6), 797-820.

Pickering, A. (1995). The mangle of practice: Time, agency and science. Chicago: University of Chicago.

Raj, M., \& Nega, M. (2011). History of trigonometry with a Classroom Application. Presented at AMATYC 37, Austin, Texas on 11 November 2011. Georgia Perimeter College.

Schmidt, N. B., Lerew, D. R., \& Jackson, R. J. (1999). Prospective evaluation of anxiety sensitivity in the pathogenesis of panic: Replication and extension. Journal of Abnormal Psychology, 108(3), 532-537. Doi: 10.1037/0021-843X.108.3.532

Schoenfeld, A. H. (1987). Cognitive science and mathematics education. New York: Routledge. Doi: $10.4324 / 9780203062685$

Simons, M. D. (2016). An ethnomethodological analysis of learners' ways of working in a high-stakes Grade 12 Mathematics National Senior Certificate (NSC) Examination: The case of Trigonometry. Unpublished PhD dissertation. University of the Western Cape.

Sofiyah, S. (2018). Analysis of students' error in proving trigonometric identities. International Journal of Management and Applied Science, 4(5), 83-86.

Thompson, P. W. (2008). Conceptual analysis of mathematical ideas: Some spadework at the foundations of mathematics education. In Proceedings of the annual meeting of the International Group for the Psychology of Mathematics Education (Vol. 1, pp. 45-64). Mexico: PME Morelia.

Walsh, R., Fitzmaurice, O., \& O’Donoghue, J. (2017). What Subject Matter Knowledge do second-level teachers need to know to teach trigonometry? An exploration and case study. Irish Educational Studies, 36(3), 273-306. Doi: 10.1080/03323315.2017.1327361

Watson, A., \& Mason, J. (2006). Seeing an exercise as a single mathematical object: Using variation to structure sense-making. Mathematical Thinking and Learning, 8(2), 91-111. Doi: $10.1207 / \mathrm{s} 15327833 \mathrm{mt} 10802 \_1$

Weber, K. (2005). Students' understanding of trigonometric functions. Mathematics Education Research Journal, 17(3), 91-112. Doi: 10.1007/BF03217423

Wenger, E. (1998). Communities of practice: Learning as a social system. Systems Thinker, 9(5), 2-3.

Wheelock, A., Bebell, D. J., \& Haney, W. (2000). What can student drawings tell us about high-stakes testing in Massachusetts? Teachers College Record, 2. Retrieved from http://www.tcrecord.org/content.asp?ContentID=10634 